\title{
An Investigation of Auditors' Responsibility for Fraud Detection in Taiwan
}

\author{
Chih-Shun Hsu (Corresponding author) \\ Department of Accounting, Tamkang University \\ New Taipei City, Taiwan \\ E-mail: cshsu@mail.tku.edu.tw \\ Fan-Hua Kung \\ Department of Accounting, Tamkang University \\ New Taipei City, Taiwan \\ E-mail: kung@mail.tku.edu.tw \\ Kieran James \\ School of Accounting, Economics and Finance, \\ University of Southern Queensland \\ Toowoomba, Australia \\ E-mail:.jamesk@usq.edu.au
}

Received: June 28, 2012 Accepted: September 13, 2012 Published: June 1, 2013

doi:10.5296/ajfa.v5i1.2020ＵRL: http://dx.doi.org/10.5296/ajfa.v5i1.2020

\begin{abstract}
Purpose - Corporate fraud is an issue that has become increasingly prevalent in the western countries and Taiwan as well. As a result, external auditors in these countries continually face widespread mistrust and criticism. It is premised that this is a manifestation of the audit expectation gap - the gap between the users' expectations of auditors and their actual role in detecting corporate fraud, as perhaps evidenced in audited financial statements. This study investigates how auditors and users perceive the auditors' responsibility for fraud detection in Taiwan.
\end{abstract}

Design/methodology/approach - A total 964 respondents were surveyed regarding their perceptions on fraud, using quantitative analysis approach. 


\section{Macrothink}

Findings - The findings indicate that a gap exists on auditors' responsibility to detect corporate fraud. The auditors strongly disagreed that they were responsible for detecting the material fraud during an audit, compared with the non-auditor groups' which strongly believed that auditors should be responsible. However, there was a general consensus by the surveyed groups that auditors should work to detect fraud that materially affects the true and fair view of financial statements, or for fraud detecting only when the audit was specifically designed for such detection.

Originality/value - The findings have important implications for auditors and the users in Taiwan, especially company directors and managers, financial analysts, investors, and bankers. This paper fills a void in research in this area and makes an interesting contribution to our understanding of fraud in Taiwan.

Keywords Audit expectation gap, Auditors' responsibilities, Fraud detection, Taiwan 


\section{Introduction}

The role of auditing had not, until 1920, been to give an opinion on the truth and fairness of the financial statements. This is now regarded as the major objective, whereas the importance of fraud detection as an audit objective is indeed downplayed (Brown, 1962; Lee, 1970; Porter, 1997). The phenomenon of downplaying auditors' responsibilities by the accounting profession resulted from its pursuit of professional (and financial) interests and its attempts to manage the interplay between its own (financial and brand-name) interests and any competing public duties and obligations (Humphrey and Moizer, 1990; Power 1995).

Sikka et al. (1998) argued that there is no possibility to eliminate the auditing expectation gap because the social context of auditing changes continuously through interaction and negotiation and the meaning of audit is changing. Public criticism of the profession's denial of responsibility for detecting fraud has stirred the auditing profession into activity since the 1980s. Efforts have been made to narrow the expectation gap by setting up commissions, such as the US Cohen Commission by AICPA (1978) and the Treadway Commission by AICPA (1987); UK Davison Report and Benson Committee by AICAW (1985a and 1985b); and Macdonald Commission by CICA (1988) in Canada (1988). These working parties have indeed suggested that auditors have an important role in detecting corporate fraud and they recommended a gradual increase in fraud detection and reporting. It is noted that they still emphasize less the issue of auditors detecting fraud as opposed to auditors reporting fraud (Porter, 1997).

This study is focused on the auditors' responsibilities to detect fraud during the time of the audit. Under the current Taiwanese auditing standard, SAS 43: The Auditor's Responsibility to Consider Fraud in an Audit of Financial Statements, the detection responsibility rests with management, but the auditor is required to maintain an attitude of professional skepticism in order to have a reasonable assurance of detecting material misstatements in the financial statements arising from error or fraud. Although the accounting profession has gradually recognized the auditor's detection responsibility, the rather vague meaning of 'reasonable assurance' is not understandable or satisfactory to the users of financial statements or the public in general. Auditors today are still facing serious criticism for failing to detect major corporate fraud during the audit process. It has also been supposed that this problem facing auditors is caused by a lack of satisfactory explanations of their role in society (Humphrey, 1997).

International literature contributes much on the expectations gap, especially on the debate about the auditor's responsibilities of fraud detection and the public's perception of her/his duties (i.e., Beck, 1973; Steen, 1990; Humphrey, Moizer, and Turley, 1993a; Porter, 1993; Koh and Woo, 2001; Leung and Chau, 2001; Lin and Chen, 2004; Fadzly and Ahmad, 2004). However, few empirical survey studies in Taiwan are available on fundamental auditing issues such as the responsibility to detect and report fraud, although increasing attention is now being paid to the legal liability issue associated with auditor negligence and audit failure (Huang et al, 1998; Tung, 1998; and Liu, 2002). Nevertheless, the debate on auditors' responsibilities and the development of expectations gaps in western countries, especially in 
the UK and US, over the last two decades are relevant to the growth of the auditing profession in Taiwan.

The purpose of the study is to provide additional evidence on the audit expectation gap. To be precise, the main focus of the study is to investigate whether there is such a gap in Taiwan's business environment. The study attempts to survey the Taiwanese auditors and users of financial statements and compare their perceptions on "what auditors should be held responsible for". Such comparison intends to examine whether there is an audit expectation gap existing amongst Taiwan's users. The findings contribute to our understanding of the auditor's duty to detect frauds and related audit procedures. Furthermore, the study findings can be compared with the results of the relevant studies carried out in other countries. In other words, we can undertake an international comparison of audit expectation gaps.

The study is structured as follows. The second section provides brief historical background, emphasizing the auditor's responsibility to detect fraud. The third section offers a review of previous empirical research. The fourth section looks at the research method, followed by the investigation results in the fifth section. The study then finishes with the discussion and conclusion section.

\section{The Auditor Responsibility for Fraud Detection}

For a long time, there has been controversy about the auditor's alleged responsibility to detect fraud. It is perhaps true to say that the role of the auditor has not been well defined since inception. The auditor's responsibility to detect fraud, as noted by Willingham (1975), was a "stated audit objective for over 400 years and was removed as an objective by the profession rather than by a change in the demand of clients of accounting firms" (cited in Humphrey, 1997, p. 15).

Since the 1920s, the accounting profession has focused progressively less on the alleged responsibility to detect fraud. This has been a result of the increase in size and complexity of business transactions which make it uneconomic for the auditor to examine all transactions (Lee, 1986). Humphrey et al (1993b) and Power (1995) attribute the change to the accounting profession's pursuit of a self-interested role and its attempts to manage the interplay between its own (financial and brand-name) interests and any competing public duties and obligations.

By the end of the 1960s, fraud detection as an auditor's responsibility was not assumed and was actually denied by the accounting profession (Porter, 1997). However, the public criticism of auditors to assume a broader responsibility for fraud detection continued through the "greed-is-good" decade of the 1980s. Political pressures arising from the profession's denial of responsibility for detecting fraud has stirred the auditing profession into initiating activities to investigate the issue. A number of working commissions were established in the USA (AICPA, 1978, Cohen Commission); UK (ICAEW, 1985a, Davison Committee); and Canada (CICA, 1988, McDonald Commission). The survey findings of the commissions consistently indicate that the majority of financial statement users and the general public, and even some of the auditors themselves, believe the auditor holds responsibility for fraud detection. However, the accounting profession still rejects extending auditor's responsibility 
to detecting fraud. This opposition is reflected by the clear statement that "the auditor was not to detect fraud and the responsibilities to prevent and detect fraud firmly rest on company management, not on the auditor of the company" (CICA 1988, ICAEW 1985).

It should be noted, nevertheless, that auditors are required to remain alert to suspicious circumstances where fraud may exist. Porter (1997) indicates that such requirement, together with the acknowledgement that sound audit procedures should uncover major frauds, imply auditor's acceptance of some responsibility to detect fraud. Since the 1980s, the profession has gradually moved in the direction of recognizing increased responsibility for fraud detection. This can be seen by the extracts from the UK SAS 110 (APB, 1995)

"...the fact that an audit is carried out may, however, act as a deterrent (para. 17).... Auditors plan, perform and evaluate their audit work in order to have a reasonable expectation of detecting material misstatements in the financial statements arising from error or fraud (para. 18).... the auditors should as soon as practicable communicate their findings to the appropriate level of management, the board of director or the audit committee if they suspect or discover the fraud... (para. 41). (APB, 1995)"

However, companies continued to collapse (Enron and WorldCom in US, BCCI and Barings Bank in UK, etc.), substantial fraud continued to occur, and funds continued to disappear go missing. Public pressure has mounted, parliament members were critical, and governments threatened regulatory legislation (Sikka et al., 1998; Dunn and Sikka, 1999). Koh and Woo (1998) suggest that one of possibilities to reduce the expectation gap is expansion of auditor's responsibilities and enhancement of auditor independence. O'Malley (1993) also agrees to imposing additional responsibilities on auditors with regard to detecting fraud by suggesting four additional responsibilities which the profession might consider: management and auditor evaluation of internal control systems; compliance reporting; direct reporting by auditors to regulators; and auditor association with interim financial information.

Nevertheless, the accounting profession has given increase to the breadth and depth of auditor's responsibilities. This is reflected, under the UK ISA240 (APB, 2005) and US AU316 (PCAOB, 2002), which emphasize the importance of exercising professional skepticism, discussion among engagement personnel regarding the risks of material misstatement due to fraud, and obtaining the information needed to identify risks of material misstatement due to fraud. The duty on fraud detection remains publicly disavowed and the accounting profession continues to stress it is the duty of management. Vanasco (1998) argues that the auditors expect to minimize legal liability by avoiding legal claims holding them responsible for fraud.

In the Taiwanese arena, virtually no change has occurred in the auditing standards with respect to the auditor's responsibility to detect fraud since the Taiwan SAS 14's inception in 1987. Taiwan's SAS 14 is the major auditing standard which regulates the auditor's responsibilities. The core concept of Taiwan's SAS 14, in similar vein to US SAS 53 (Chen, 2004), is that responsibilities to prevent and detect fraud and errors lie with company management. However, auditors should plan and perform their audit work with due care so that material misstatements in the financial statements arising from fraud or error can be 
uncovered. No responsibility for reporting fraud is involved when the auditor discovers fraud during her/his audit.

Prior to 2000, the Taiwan professional body's system of Practice Review with respect to the auditor's duty to detect fraud was not discussed in the public domain. Little publicity is given to sanctions imposed on errant auditors identified by the monitoring of auditors' performance, information about monitoring process and its outcomes.

Fraudulent activities across business have increased in the last two decades. Amongst them, Procomp Informatics Ltd. was one case infamous enough to be deemed the Taiwan version of the US Enron financial fraud. By the end of June 2004, Procomp's NT\$40 billion (USD\$1.3 billion) fallout rocked the Taiwanese market and brought about scathing criticism of the accounting profession. Other fraud episodes include Infodisk Technology's NT\$4.28 billion in losses relating to the investment in 2004, and the illegal over-due loans made to its subsidiaries by Chung-shing Bank resulted in NT\$11 billion bad-debt loss in 2000. During the 1990s, well-known fraud cases are Tung-lung Metal Industry Co's fraudulent activity made by its CEO which resulted in a loss of NT\$2.4 billion (USD\$80 million) in 1998 from avoiding short-term investment loss realization by the shift to long-term investment without authorization, and Taiwan International Securities Company suffered loss of NT\$10 billion (USD \$330 million) in 1994 because of the false transaction made by a junior staff.

The above corporate frauds in Taiwan have not only resulted in huge losses of money and public confidence in auditors but have also placed the spotlight of the debate on auditors' responsibility to detect and report fraud. However, the Government, various pressure groups, and the general public do not favor the status quo.

Influenced by circumstances that led to the passage of Sarbanes-Oxley Act (SOX), the government authority, Financial Supervisory Commission, began seriously to explore ways to raise CPA audit standards and effect a robust Practice Review system in Taiwan. Regrettably, not pursuing the idea of employing an outside regulatory agency such as PCAOB to be its supervisor and overseer, the Practice Review system has still relied on the most part on Taiwan CPA Association's self-regulatory functions, which are supported and endorsed by the CPA Act amendment 2007 (Wu, 2007).

In Taiwan, the current audit standards regulating body is Accounting Research and Development Foundation (ARDF). As a foundation, ARDF's income derives mainly from the donations by CPA Association, with the exception of some income derived from selling publications and holding accountant professional training seminars. The conflict of interest relating to income sources at the Association not only hampers ARDF in its standard-setting efficiency, but also renders it ineffectual when it comes to promoting audit standards for the public good and interest. This is not conducive to the healthy development of Taiwan's accountancy profession.

In September 2006, Taiwan auditing setting body, responding to the public criticism and debates on the auditor's responsibilities to detect and report fraud, issued SAS 43: The Auditor's Responsibility to Consider Fraud in an Audit of Financial Statements. The Taiwan's 
SAS 43 adopted currently, referring to US SAS 99 and UK SAS 110, recognizes the auditor's responsibility to report fraud, and consideration of fraud risk factors during the audit (Ma, 2006). It points out that the detection responsibility rests with management. However, it spells out the responsibility as adherence to GAAS, namely that the auditor is required to maintain an attitude of professional skepticism in order to have a reasonable assurance of detecting material misstatements in the financial statements arising from error or fraud.

\section{Evidence from Empirical Studies}

The debate about the auditor's responsibility to detect fraud reveals that there are expectation gaps within the accounting profession itself concerning the proper conduct of an audit, as well as between public expectations and auditor performance. Liggio (1974) was the first to define the term 'expectation gap' as difference of the levels of expected performance as envisioned both by the independent accountant and by the user of financial statements. The term became prevailing usage in the auditing literature after the conclusions and recommendations of the Cohen Report on auditors' responsibilities (AICPA, 1978). Porter (1993) extended the definitions as the gap between society's expectations of auditors and auditors' performance as perceived by society. By embracing the notion of the reasonableness and expected performance, she adopted the title 'audit expectation-performance gap', and proposed two major components, namely, the 'reasonableness gap' and the 'performance gap'. The latter is constructed as the sum of the 'deficient standards gap' and the 'deficient performance gap'.

Numerous empirical studies of the audit expectation gap have been conducted since 1970 in many countries. Beck (1973) surveyed Australian shareholders in 1972 and obtained 711 usable responses (46\% response rate). Beck's findings were that the professional assurances that shareholders expect from the auditors far exceed what the auditor would consider reasonable or even possible.

Baron et al. (1977) conducted a survey in 1975 to learn the extent of any expectations gap. Questionnaires were sent to large firm audit partners (105); small firm CPA (35); bank loan officers (83); financial managers (79); and financial analysts (52). The study found the existence of audit expectation gap whereby non-auditors thought auditors should take more responsibility to detect the deliberate material falsification of the financial statements. The partners of large firms were the group proclaiming least responsibility to detect deliberate falsification.

Further evidence in the 1980s was provided by the MacDonald Commission (CICA, 1988). One thousand respondents were interviewed by telephone and, as far as fraud was concerned, $47 \%$ of those questioned believed that auditors should actively seek fraud.

The Steen survey (1990), conducted by means of face-to-face interviews in the UK, comprised 1,737 usable respondents who were divided into three categories: (1) 'influential' were those who said they were chairman, director or senior partner in a company; (2)the 'financially aware', were those in a position to influence audit appointments and familiar with audit financial statements, and who owned shares and actively managed their own share 
portfolio or financial affairs; (3) the remainder of the respondents who were not familiar with audited financial statements. The survey revealed that the widely held opinion that fraud detection is an important part of the auditor's job, and showed clearly that there exists an expectations gap regarding fraud detection gap of considerable proportions.

Humphrey et al. (1993a) conducted a questionnaire survey between October 1990 and March 1991. A $38 \%$ response rate was achieved which equated to 935 usable replies. The six categories of interviewees were: auditors, accountants, financial directors, investment analysts, bankers, and financial journalists. The evidence indicated that preparers, users and even auditors saw auditors as having a role to ensure that all significant fraud is detected, but they did not feel that auditors currently offer significant protection against fraud.

Porter (1993) conducted a survey in New Zealand in 1989 to ascertain the opinions of auditors' interest groups about auditors' existing responsibilities, the standard of performance of those responsibilities, and the responsibilities auditors should take upon themselves. The usable 1,184 responses from four groups (auditors, auditees, financial community, and the general public) revealed the presence of an expectation gap between auditors and non-auditors. The study calculated the size of the gaps and found that the deficient performance gap, deficient standards gap, and unreasonableness expectation gap contributed $11 \%, 58 \%$, and $31 \%$ respectively. In 1999, Porter and Gowthorpe (2004) replicated Porter's 1989 study in both NZ and the UK and found that the composition of the audit expectation-performance gap has changed significantly over the decade from 1989 to 1999. The 1999 study showed the sizes of the deficient performance gap, deficient standards gap, and unreasonableness expectation gap have changed to $6 \%, 53 \%$, and $41 \%$, respectively. Porter and Gowthorpe indicated (2004) that auditors' performance of their responsibilities has improved so that the performance gap has narrowed. However, society's expectations of auditors have increased to a level that more than offsets this improvement. They further recommended four measures to be implanted to narrow the performance gap: continued and strengthened monitoring of auditors' performance; improving quality controls in audit firms; enhancing education of the auditing practitioners; and introducing new auditing standards. As to narrowing the reasonableness gap, they suggested the need for society to be better educated about the audit function and what auditors can reasonably be expected to achieve.

Other studies in emerging economies have provided the evidence identifying the existence of the expectation gap. Most of these studies were undertaken by means of surveys designed to ascertain the opinions of different interest groups about the auditor's responsibilities and the audit objectives. They are, for example, the investigations by Gloeck and Jager (1993) in the Republic of South Africa; Leung and Chau (2001) in Hong Kong; Low, Foo, and Koh (1988) and Best, Buckby and Tan (2001) in Singapore; Fadzly and Ahmad (2004) in Malaysia; Lin and Chen (2004) in China; Chowdhury, Inn and Kouhy (2005) in Bangladesh; Dixon, Desira and Baldacchino (2005) in Malta; Woodhead and Sohliman (2006) in Egypt; Sidani (2007) in Lebanon. Most studies above consistently found the existence of the audit expectation gap in the area of the auditor's responsibility, reliability of audited financial statement, and auditor's independence or accountability. 
Results from a string of empirical studies stretching over the last 40 years or so have been examined. They confirm the historical analysis made earlier, namely that the gradual move away from fraud detection as the main audit objective, which solidified in the second half of the 20th century, is not a view shared by the public. Not only do the views differ between the accountancy profession and audit beneficiaries, they differ considerably. The percentage of survey respondents who wanted the auditor's role to embrace fraud detection is substantial. It is pertinent to note also that such views have, in broad terms, remained consistent over time despite general exhortations from the profession and educational publicity to change the so-called ignorance gap.

\section{Research Method}

Whether the accounting profession in Taiwan has met the public's expectations is an issue worth investigating. This empirical investigation are to ascertain the nature of audit expectations gap with respect to the auditor's responsibilities to detect corporate fraud. In order to examine this issue, the following statements are developed and tested:

1. The auditor should be held responsible for the failure to detect material fraud in an ordinary audit examination.

2. The auditor should be held responsible for failure to detect material fraud in a detailed audit examination specifically designed for such detection.

3. The auditor should be held responsible for failure to detect material fraud when collusion exists among employees below management level.

4. The auditor should be held responsible for failure to detect material fraud when collusion exists at the management level.

5. The auditor should be held responsible for failure to detect material fraud in situations where the irregularities are a result of unrecorded transactions.

6. The auditor should be held responsible for failure to detect fraud that materially affects the true and fair view of financial statements.

7. The auditor should be held responsible for failure to detect material fraud that is perpetrated and concealed through related party transactions (i.e., shares trading irregularly between affiliated companies).

8. The auditor should be held responsible for failure to detect the type of material frauds (such as embezzlement) that serve to personally enrich managers, officers, or directors of an entity.

9. The auditor should be held responsible for failure to detect the type of material frauds (such as petty cash theft, payroll padding, theft of stocks) that are committed to personally enrich employees below management level.

10. The auditor should be held responsible for failure to detect material, deliberate falsifications and misrepresentations of financial statements that are committed for the 
purpose of defrauding the investing public.

A choice of six alternative responses for each statement is designed, and the respondents are asked to give one level of agreement. In order to eliminate the bias of analysis that the respondents may not have background knowledge about the auditor's responsibility for fraud detection, the 'don't know (coded 0)' choice is given in the questionnaire but excluded in analyzing. Therefore, the five choices of level of agreement, excluding the 'don't know' choice, were calculated by using the five-point Likert scale, varying from 'Strongly Agree (coded 5)' on the left hand side of the scale to 'Strongly Disagree (coded 1)' on the right hand side of the scale.

The analysis is made of the differences in the mean ranking based on the Wilcoxon-Mann-Whitney test. The Wilcoxon-Mann-Whitney test has been adopted to establish whether apparent differences of opinion between the survey groups are statistically significant. The Wilcoxon-Mann-Whitney test was chosen because it could test differences in means of the two populations without having to test for normality of distribution. Where significant differences were found amongst five groups within these tables of results, it may be claimed that the auditors are expected to be held responsible for the detection of the fraud (Siegel and Castellan, 1989)

For the purpose of this study, three groups were selected. They are auditor group, auditee group consisting of financial directors, CEOs, or accounting managers from Taiwanese Top-500 public companies; and the group of users of financial statements, consisting of financial analysts and bank loan officers. The subgroups of the auditee are regarded as the preparers of financial statements.

A total of 964 questionnaires were mailed. In order to increase the response rate, follow-up of non-respondents was done by 669 duplicate copies of the questionnaire and original letters of explanation, 340 of which went to members of the auditor group, 116 to members of the auditee group, and 213 to the members of the users of financial statements group. Of the 964 members surveyed, there were 341 usable responses, a 35\% return rate for data analysis. This is a very satisfactory response rate within an East-Asian context.

\section{Investigation Results}

As the respondent group of the users of financial statements consists of financial analysts, institutional investors, and bank loan officers, who represent different beneficiary interests with respect to accounting information, the analysis is thus undertaken by comparing the surveyed opinions of auditor's responsibility between the five major respondent groups. Difference of opinions within the user group was also identified. The descriptive statistics of the survey results are exhibited in Table 1, where the means and standard deviations for each statement responses are provided. In addition, Table 2 shows Wilcoxon-Mann-Whitney test results which examine whether differences are evident in the opinion results between respondent groups. The summary and overview of the respondents' opinions is provided in Table 3.

It is acknowledged that, although judgment of the performance of auditors' responsibilities 
involves a range of spectrums, rather than a point of measurement, for the purpose of this study, 3 has been selected as the point of differentiation (average of sum by 1 to 5). By doing so arbitrariness will decrease, and objectivity increase.

On average, in the overall group analysis, three of the statements are not perceived as the auditor's responsibility for fraud detection. This is shown in the Table 1 , by having means results of less than three. These three statements are:

Statement 3: The auditors should be held responsible for the failure to detect material fraud when collusion exists among employees below the management level.

Statement 4: The auditors should be held responsible for the failure to detect material fraud when collusion exists at the management level.

Statement 9: The auditors should be held responsible for the failure to detect the type of material frauds (such as petty cash theft, payroll padding, or theft of stocks) which are committed to personally enrich employees below management level.

The overall group perception of the above three statements is consistent with the responses of the financial analyst group, but bank loan officer group only agrees with the statement 3 and statement 9 which are not auditor's duties. It should be noted that both auditee and institutional investor groups agree with all the ten statements which claim that the auditors are responsible for fraud detection. By contrast, the auditor group agrees only with four of them. The auditor group considers only the following statements as their responsibilities:

Statement 2: The auditors should be held responsible for the failure to detect material fraud in a detailed audit examination specifically designed for such detection.

Statement 6: The auditors should be held responsible for the failure to detect fraud that materially affects the true and fair view of financial statements.

Statement 7: The auditors should be held responsible for the failure to detect material fraud perpetrated and concealed through related party transactions.

Statement 10: The auditors should be held responsible for the failure to detect material, deliberate falsifications and misrepresentations of financial statements that are committed for the purpose of defrauding the investing public.

It is interesting to note, however, that the above four responsibilities do not have statistically significant differences in the mean responses between the auditor group and the auditee group according to the Wilcoxon-Mann-Whitney test in Table 2. The results indicate that the auditors perceive their responsibilities only within the existing auditing standard requirements, which they are reasonably expected to perform the duty to detect. The prescriptions in existing auditing standards express that auditors should issue the audit report stating whether the financial statements be presented with a true and fair view. Any material misstatements caused by deliberate falsifications or distortions would have material effects on the true and fair view of the financial statements.

There is a strong consensus by both auditor and non-auditor groups that auditors should be 
held responsible for fraud detection in a design specifically to search for fraud (Statement 2) and for detection of fraud that materially affects the true and fair view of financial statements (Statement 6).

However, the non-auditor group would not merely expect the auditor's responsibility within the scope of existing auditing standards but expect auditors to expand the responsibility to detect all type of frauds including the collusion amongst the employees below management level. The significant differences of opinions are between the auditor and institutional investor groups, and between the auditor and bank loan officer group. The similar result can be found in the comparison between auditor group and financial analyst group, except for Statement 3. The results of Wilcoxon-Mann-Whitney test (see Table 2) reveal that there is no generalized conclusion that can be drawn about the statistically significant differences of the responses between the groups.

To sum up, the results indicate the existence of the expectation gap in terms of the auditor's duties to detect the material fraud, during an ordinary audit examination; that material fraud perpetrated by employees below management level; and that material fraud concealed through related-party transactions. Table 3 provides a summary and overview of the opinions.

\section{Discussion and Conclusions}

The paper has investigated, amongst auditor and non-auditor groups, the perceptions regarding the auditor's responsibility to detect corporate fraud. The findings indicate the expectation gap existing in Taiwan. The non-auditor groups are expecting greater responsibility from auditors with respect to detecting fraud than the auditor group, which agrees only with the detection responsibility required in the Taiwanese existing standards. It appears that adequateness of the auditing standard with respect to the auditor responsibility needs to be considered and maintained.

To ensure that the accounting profession is perceived by interested outside parties to be maintaining the fraud detection standards, it is suggested that publicity of disciplinary action be increased, not merely relying on the self-regulation as a monitoring mechanism. Self-regulation is not enough for building up the confidence of the public.. To increase public confidence in the adequacy of the disciplinary procedures of the profession, it is also suggested that the auditing standards-setting body must not just be comprised of accounting professionals but include distinguished members from diverse sectors of society. Through their involvement, financial statement audit procedures can be made more transparent and public awareness heightened, so that CPAs in their financial audit and standards-setting capacities can, while functioning under a self-regulatory institution, better conform to the principles of what is termed 'commonly accepted'.

The fact that auditors in Taiwan do not see the detection of fraud as their responsibility, but rather see their role as expressing an independent opinion on financial statements is an indication that they still need to be aware that undetected fraud could distort their findings and affect the reliability of their audit reports. Furthermore, from an ethical viewpoint, the auditors should act as a watchdog that is responsible for reporting any suspicion of fraud 
rather than remaining silent.

Education and communication may be a key to solving part of the problem as to how auditors regard their role, by closing the 'misunderstanding gap' although the expectation gap may still exist. Not only must auditors know what their responsibilities are, and possess the technical competence required to fulfill them satisfactorily, they must also develop and maintain professional attitudes. In particular, the professional standards of integrity, independence and service above reward must be instilled in them.

Users in Taiwan, on the other hand, may need to be well informed through the provision of a precise and detailed engagement letter and the audit report. Such a report should be sufficiently standardized to avoid confusion amongst readers as to its basic message (i.e., reasonable assurance). However, it must also be flexible enough for auditors to report clearly concerns they have about the company. It is suggested that the auditors in Taiwan explicitly be required to add a paragraph to the audit report explaining the position in cases where they have doubts about the viability of the auditee company.

The study contributes our understanding of the auditor's duty to detect frauds and possible suggestions provided in an attempt to bridge the expectation gap in Taiwan. Moreover, it is submitted that the investigation findings make a particular and valuable contribution to extending the international literature regarding the audit expectation gap.

Future research may consider both longitudinal studies and comparative studies overseas by sending a large-scale self-administered questionnaire to remove any potential bias. Further study into this area could also be undertaken to investigate the functional and operational aspects of auditing for fraud. Detailed micro case studies of how major frauds were both perpetrated and detected will also be important (see e.g. Lam et al., 2011).

\section{References}

AICPA. (1978). Report Conclusions and Recommendations of the Commission on Auditors' Responsibilities, AICPA, New York.

AICPA. (1987). Report of the National Commission on Fraudulent Financial Reporting (Treadway Commission), AICPA, New York.

APB. (2005). ISA (UK and Ireland) 240: The Auditor's Responsibility to Consider Fraud in an Audit of Financial Statements, ICAEW, London.

Auditing Practices Board. (2004). Ethical Standards for Auditors, Financial Reporting Council, London.

Baron, C., Johnson, D., Searfoss, D. and Smith, C. (1977). Uncovering corporate irregularities: Are we closing the expectations gap?" Journal of Accountancy, 144(4), 56-66.

Beck, G.W. (1974). The role of the auditor in modern society: An empirical appraisal. Accounting and Business Research, 4, 117-122.

Best, P., Buckby, S. and Tan, C. (2001). Evidence of the audit expectation gap in Singapore. 
Managerial Auditing Journal, 16(3), 133-44. http://dx.doi.org/10.1108/02686900110385579

Brown, R. G. (1962). Changing audit objectives and techniques. The Accounting Review, 37(4), 696-703.

Burrowes, A.W., Kastantin, J. and Novicevic, M. (2004). The Sarbanes-Oxley Act as a hologram of post-Enron disclosure: A critical realist commentary. Critical Perspectives on Accounting, 15(6), 797-811. http://dx.doi.org/10.1016/j.cpa.2003.06.006

Cheng, H. (2004). The responsibility for financial statements audit: it is not absolute assurance. Accounting Research Monthly, 220, 53-58. (in Chinese)

Chowdhury, R., Innes, J. and Kouhy, R. (2005). The public sector audit expectations gap in Bangladesh. Managerial Auditing Journal, 20(8), 893-908. http://dx.doi.org/10.1108/02686900510619719

CICA. (1988). Report of the commission to study the public's expectations of audits, Canadian Institute of Chartered Accountants, Toronto.

Desira, J. and Baldacchino, P. J. (2005). Jurors' and self-perceptions of the statutory auditors in Malta. Managerial Auditing Journal, 20(7), 691-706. http://dx.doi.org/10.1108/02686900510611230

Dixon, R., Woodhead, A.D. and Sohliman, M. (2006). An investigation of the expectation gap in Egypt. Managerial Auditing Journal, 21(3), 293-302. http://dx.doi.org/10.1108/02686900610653026

Dunn, J. and Sikka, P. (1999). Auditors: Keeping the Public in the Dark, Association for Accountancy and Business Affairs, Basildon, UK.

Fadzly, M.N. and Ahmad, Z. (2004). Audit expectation gap: The case of Malaysia. Managerial Auditing Journal, 19(7), 897-915. http://dx.doi.org/10.1108/02686900410549420

Farrel, B. and Franco, J. (1999). The role of the auditor in the prevention and detection of business fraud: SAS No.82. Western Criminology Review, 2(1), 1-12.

Flint, D. (1971). The role of the auditor in modern society: An exploratory essay. Accounting and Business Research, 1(4), 287-293. http://dx.doi.org/10.1080/00014788.1971.9728980

Gloeck, J.D. and Jager, H. (1993), The audit expectation gap in the Republic of South Africa, Working Paper, School of Accountancy, University of Pretoria.

Huang, C., Lin, L.Y. and Chen, H. (1998). The discussion on the liability of Taiwanese auditing attestation: Recent litigation cases. Accounting Research Monthly (in Chinese), 153, August, pp. 76-82.

Humphrey, C. (1997). Debating audit expectations. In Shere M, Turley S, editors. Current Issue in Auditing, Paul Chapman Publishing, London, pp. 3-29.

Humphrey, C., Turley S. and Moizer, P. (1993b). Protecting against detection: the case of auditors and fraud?" Accounting, Auditing, and Accountability Journal, 6(1), 395-411. 
http://dx.doi.org/10.1108/09513579310027512

Humphrey, C.G. and Moizer, P. (1990). From techniques to ideologies: An alternative perspective on the auditing function. Critical Perspectives on Accounting, 1(3), 217-238. http://dx.doi.org/10.1016/1045-2354(90)03021-7

Humphrey, C.G., Moizer, P. and Turley, W. S. (1993a). The audit expectations gap in Britain: An empirical investigation. Accounting and Business Research, 23(91A), 395-411.

ICAEW. (1985a). Report of the Working Party on Fraud (Davison Report), ICAEW, London.

ICAEW. (1985b). The Auditor and Fraud: Report of Lord Benson's Committee, ICAEW, London.

Koh, H.C. and Woo, E. (1998). The expectation gap in auditing. Managerial Auditing Journal, 13(3), 147-154. http://dx.doi.org/10.1108/02686909810208038

Koh, H.C. and Woo, E. (2001). The auditor-manager expectation gap in auditing. Managerial Auditing Journal, 6(3), 176-88.

Lam, J., James, K. and Leung, J.K.-S. (2011). The rebuilding of a life after jail time for fraud. Unpublished Working Paper, University of Southern Queensland, Toowoomba, Australia.

Lee, T. (1970). The nature of auditing and its objectives. Accountancy, 81, 292-296.

Lee, T. (1986), Company Auditing (3rd ed.), Chapman and Hall, London.

Leung, P. and Chau, G. (2001). The problematic relationship between audit reporting and audit expectations: Some evidence from Hong Kong. Advances in International Accounting, 14, 181-200. http://dx.doi.org/10.1016/S0897-3660(01)14010-9

Liggio, C.D. (1974). The expectation gap: the accountant's legal Waterloo. Journal of Contemporary Business, 3, 27-44.

Lin, Z.J. and Chen, F. (2004). An empirical study of audit 'expectation gap' in the People's Republic of China. International Journal of Auditing, 8(8), 92-115.

Liu, C.W. (2002). CPA's licensing requirement, legal liability, and the audit market. Journal of Management (in Chinese), 19(1), 109-145.

Low, A.M., Foo, S.L. and Koh, H.C. (1988). The expectation gap between financial analysts and auditors —-some empirical evidence. Singapore Accountant, 4, 10-13.

Lys, T. and Watts, R.L. (1994). Lawsuit against auditors. Journal of Accounting Research, 32, 65-93. http://dx.doi.org/10.2307/2491440

Ma, X.R. (2006). Auditor's role in capital market: Fraud detection responsibility. Gre-Tai Securities Market Monthly (in Chinese), 123, 31-41.

Mitchell, A., Sikka, P. and Willmott, H. (1998), The accountants' Laundromat, Association for Accountancy and Business Affairs, UK. 
O'Malley, S.F. (1993). Legal liability is having a chilling effect on the auditor's role. Accounting Horizons, 7, 82-87.

O'Sullivan, N. (1993). Auditors' liability: Its role in the corporate governance debate. Accounting and Business Research, 23(91A), 412-420.

PCAOB, (2002), AU 316: Consideration of Fraud in a Financial Statement Audit, Public Company Accounting Oversight Board, New York:

Porter, B. (1993). An empirical study of the audit expectation-performance gap. Accounting and Business Research, 24(93), 49-68. http://dx.doi.org/10.1080/00014788.1993.9729463

Porter, B. (1997). Auditors' responsibilities with respect to corporate fraud: A controversial issue. In Shere M, Turley S, editors, Current Issue in Auditing. Paul Chapman Publishing, London, pp. 31-54.

Porter, B.A. and Gowthrope, C. (2004). Audit expectation-performance gap in the UnitedKingdom in 1999 and comparison with the gap in New Zealand in 1989 and 1999, Institute of Chartered Accountants of Scotland, Edinburgh.

Power, M. (1995). Auditing, expertise, and the sociology of technique. Critical Perspectives on Accounting, 6(4), 317-339. http://dx.doi.org/10.1006/cpac.1995.1029

Sidani, M.J. (2007). The audit expectation gap: Evidence from Lebenon. Managerial Auditing Journal, 22(3), 288-302. http://dx.doi.org/10.1108/02686900710733152

Siegel, S. and Castellan, J. (1989) Nonparametric Statistics: For the behavioral sciences $\left(2^{\text {nd }}\right.$ Ed.), McGraw-Hill, Singapore.

Sikka, P. (2004). Some questions about the governance of auditing firms. International Journal of Disclosure and Governance, 1(2), 186-200. http://dx.doi.org/10.1057/palgrave.jdg.2040023

Sikka, P., Puxty, A., Willmott, H. and Cooper, C. (1998). The impossibility of eliminating the expectations gap: Some theory and evidence. Critical Perspectives on Accounting, 9(3), 299-330. http://dx.doi.org/10.1006/cpac.1997.0159

Steen, M. (1990). Audits and auditors: What the public thinks, KPMG, London.

Tung, K.P. (1998). The prevention of corporate financial distress: The case of Tong Lung Metal Industry. Accounting Research Monthly (in Chinese), 157, 31-36.

Vanasco, R. (1998). Fraud and Auditing. Managerial Auditing Journal, 13(1), 4-71. http://dx.doi.org/10.1108/02686909810198724

Willingham, J.J. (1975). Discussant's response to the relationship of auditing standards to the detection of fraud. The CPA Journal, 18-21.

Woolf, E. (1987). Bridging the gap: The role of the auditor. The Chartered Accountant in Australia, 57(9), 22-23. 


\section{Macrothink}

Asian Journal of Finance \& Accounting

ISSN 1946-052X

2013, Vol. 5, No. 1

$\mathrm{Wu}$, C.F. (2007). The changing environment in CPA practice: the implication of CPA Act amendment. Accounting Research Monthly, 265, 12-19.

Table 1. Descriptive statistics by subgroups of respondents

\begin{tabular}{lcccccccccccc}
\hline & Overall Group & Auditors & \multicolumn{1}{c}{ Auditees } & \multicolumn{7}{c}{ Financial Analysts Institutional Investors Bank Loan Officers } \\
\cline { 2 - 12 } & Means & S.D. & Means & S.D. Means S.D. & Means & S.D. & Means & S.D. & Means & S.D. \\
\hline Statement 1 & 3.75 & 1.04 & 2.71 & 0.97 & $4.38^{*}$ & 0.73 & $3.82^{*}$ & 0.82 & $4.72^{*}$ & 0.46 & $3.93^{*}$ & 0.35 \\
Statement 2 & 4.31 & 0.63 & 4.00 & 0.53 & 4.51 & 0.74 & 4.33 & 0.56 & 4.68 & 0.48 & 4.28 & 0.55 \\
Statement 3 & 2.53 & 1.08 & 1.83 & 0.62 & $3.36^{*}$ & 0.80 & 2.10 & 0.94 & $3.88^{*}$ & 0.88 & 2.42 & 0.84 \\
Statement 4 & 2.69 & 1.15 & 1.78 & 0.61 & $3.37^{*}$ & 0.81 & 2.33 & 1.12 & $4.00^{*}$ & 0.91 & $3.25^{*}$ & 0.98 \\
Statement 5 & 3.63 & 0.98 & 2.64 & 0.92 & $4.11^{*}$ & 0.59 & $3.72^{*}$ & 0.85 & $4.60^{*}$ & 0.50 & $4.05^{*}$ & 0.32 \\
Statement 6 & 4.14 & 0.65 & 3.83 & 0.66 & 4.26 & 0.57 & 4.21 & 0.69 & 4.68 & 0.48 & 4.08 & 0.47 \\
Statement 7 & 3.85 & 0.80 & 3.13 & 0.89 & $4.16^{*}$ & 0.58 & $4.09^{*}$ & 0.59 & $4.40^{*}$ & 0.50 & $3.95^{*}$ & 0.32 \\
Statement 8 & 3.31 & 1.09 & 2.23 & 0.71 & $3.86^{*}$ & 0.80 & $3.46^{*}$ & 1.05 & $4.36^{*}$ & 0.70 & $3.58^{*}$ & 0.71 \\
Statement 9 & 2.98 & 1.09 & 2.26 & 0.81 & $3.76^{*}$ & 0.69 & 2.77 & 1.05 & $4.32^{*}$ & 0.75 & 2.48 & 0.85 \\
Statement 10 & 3.89 & 0.86 & 3.09 & 0.89 & $4.37^{*}$ & 0.66 & $4.01^{*}$ & 0.62 & $4.60^{*}$ & 0.50 & $3.95^{*}$ & 0.39 \\
\hline
\end{tabular}

* indicates that statistically generalised conclusion can be drawn about the difference in opinions from the auditor group ( $\mathrm{p} \leqq 0.05$ ), based on Wilcoxon-Mann-Whitney test.

Table 2. Auditing function expected of auditors toward fraud detection results of wilcoxon-mann whitney test to responses

\begin{tabular}{|c|c|c|c|c|c|c|c|c|}
\hline & \multicolumn{2}{|c|}{$\begin{array}{l}\text { Auditors } \\
\text { vs. } \\
\text { Auditess }\end{array}$} & \multicolumn{2}{|c|}{$\begin{array}{c}\text { Auditors } \\
\text { vs. } \\
\text { Financial Analysts }\end{array}$} & \multicolumn{2}{|c|}{$\begin{array}{c}\text { Auditors } \\
\text { vs. } \\
\text { Inst'l Investors }\end{array}$} & \multicolumn{2}{|c|}{$\begin{array}{c}\text { Auditors } \\
\text { vs. } \\
\text { Bank Loan Officers }\end{array}$} \\
\hline & $\mathrm{Z}$ & $\begin{array}{l}\text { Sig. } \\
\text { Prob. }\end{array}$ & Z & $\begin{array}{l}\text { Sig. } \\
\text { Prob. }\end{array}$ & Z & $\begin{array}{l}\text { Sig. } \\
\text { Prob. }\end{array}$ & Z & $\begin{array}{l}\text { Sig. } \\
\text { Prob. }\end{array}$ \\
\hline Statement 1 & -9.65 & 0.00 & -6.98 & 0.00 & -7.36 & 0.00 & -6.47 & 0.00 \\
\hline Statement 2 & -6.68 & 0.00 & -4.42 & 0.00 & -6.18 & 0.00 & -2.90 & 0.00 \\
\hline Statement 3 & -10.19 & 0.00 & -1.83 & 0.07 & -7.64 & 0.00 & -4.45 & 0.00 \\
\hline Statement 4 & -10.27 & 0.00 & -3.54 & 0.00 & -7.67 & 0.00 & -7.36 & 0.00 \\
\hline Statement 5 & -9.14 & 0.00 & -6.42 & 0.00 & -7.23 & 0.00 & -6.44 & 0.00 \\
\hline Statement 6 & -5.00 & 0.00 & -4.13 & 0.00 & -6.78 & 0.00 & -2.09 & 0.04 \\
\hline Statement 7 & -7.66 & 0.00 & -6.83 & 0.00 & -5.97 & 0.00 & -4.36 & 0.00 \\
\hline Statement 8 & -10.05 & 0.00 & -7.55 & 0.00 & -7.95 & 0.00 & -7.76 & 0.00 \\
\hline Statement 9 & -9.75 & 0.00 & -3.64 & 0.00 & -7.75 & 0.00 & -2.12 & 0.03 \\
\hline Statement 10 & -8.92 & 0.00 & -7.13 & 0.00 & -6.65 & 0.00 & -5.46 & 0.00 \\
\hline
\end{tabular}

$\square$ indicates that no statistically generalised conclusion can be drawn about the difference in opinions between the survey groups regarding this statements. 
Table 3. Summary and overview of the survey groups' opinions

\begin{tabular}{cccccc}
\hline & Auditors & Auditees & $\begin{array}{c}\text { Financial } \\
\text { Analysts }\end{array}$ & $\begin{array}{c}\text { Institutional } \\
\text { Investors }\end{array}$ & $\begin{array}{c}\text { Bank Loan } \\
\text { Officers }\end{array}$ \\
\hline Statement 1 & $x^{\mathrm{a}}$ & $\sqrt{ }$ & $\sqrt{ }$ & $\sqrt{ }$ & $\sqrt{ }$ \\
Statement 2 & $\sqrt{ }$ & $\sqrt{ }$ & $\sqrt{ }$ & $\sqrt{ }$ & $\sqrt{ }$ \\
Statement 3 & $x$ & $\sqrt{ }$ & $x$ & $\sqrt{ }$ & $\times$ \\
Statement 4 & $x$ & $\sqrt{ }$ & $x$ & $\sqrt{ }$ & $\sqrt{ }$ \\
Statement 5 & $x$ & $\sqrt{ }$ & $\sqrt{ }$ & $\sqrt{ }$ & $\sqrt{ }$ \\
Statement 6 & $\sqrt{ }$ & $\sqrt{ }$ & $\sqrt{ }$ & $\sqrt{ }$ & $\sqrt{ }$ \\
Statement 7 & $x$ & $\sqrt{ }$ & $\sqrt{ }$ & $\sqrt{ }$ & $\sqrt{ }$ \\
Statement 8 & $x$ & $\sqrt{ }$ & $\sqrt{ }$ & $\sqrt{ }$ & $\sqrt{ }$ \\
Statement 9 & $x$ & $\sqrt{ }$ & $x$ & $\sqrt{ }$ & $\times$ \\
Statement 10 & $x$ & $\sqrt{ }$ & $\sqrt{ }$ & $\sqrt{ }$ & $\sqrt{ }$ \\
\hline
\end{tabular}

a: $x$ indicates the statement is not considered as the auditor's responsibility.

b: $\sqrt{ }$ indicates the statement is considered as the auditor's responsibility. 